\title{
Appraisal of Information and Communication Technology Courses in Business Education Programme of Universities in South East Nigeria
}

\author{
Ile, Chika Madu ${ }^{1} \&$ Ementa, Christiana Ngozi ${ }^{1}$ \\ ${ }^{1}$ Department of Vocational Education, Nnamdi Azikiwe University, Awka, Nigeria \\ Correspondence: Ementa, Christiana Ngozi, Department of Vocational Education, Nnamdi Azikiwe University, \\ Awka, Nigeria
}

Received: November 26, 2015

Accepted: December 17, 2015

Online Published: December 28, 2015

doi:10.5430/ijhe.v5n1p200

URL: http://dx.doi.org/10.5430/ijhe.v5n1p200

\begin{abstract}
The trend of Information and Communication Technology (ICT) usage in the business world necessitates that business education students be fortified with ICT skills as to be relevant and highly valued in the job market. The purpose of the study was to examine the four-year standard academic degree programme in business education department of five universities in South East, Nigeria. It x-rayed the semester courses in the programme which revealed word processing and spreadsheet processing as the only ICT skill course in the programmes. It was recommended among others that business education curriculum of universities be revisited and upgraded to incorporate more ICT skill courses that will provide students with requisite ICT skills for employability and self-reliance.
\end{abstract}

Keywords: Information and Communication Technology, Business Education Programme

\section{Introduction}

Information and Communication Technology (ICT) has rapidly changed and revolutionized the nature and course contents of tertiary institutions educational programme. These technological changes have facilitated the paradigm shift from traditional pedagogical methods to innovative technological based teaching and learning methods imbedded in school educational programmes (Ubulom, Enyekit, Onuekwa and Amaehule, 2011). The inclusion of modern technologies in institution's programme prompted a swift shift from the use of traditional instructional equipment to modern technological devices so as to move on with the tide of global technological advancement. Business education is an institutions' programme that utilize diverse technologies to promote and enhance teaching and learning (Etonyeaku, 2012). Objectives of business education at the university level according to NUC (2007) are to;

- Assist the education sector by producing a committed and efficient breed of business education teachers for the junior and senior sections of the Nigerian secondary schools.

- Produce the manpower endowed with analytical and critical knowledge of the major factors in contemporary business world to influence the development of a virile economy.

- Provide a course of instruction and all necessary facilities and exposure for the pursuit and acquisition of learning and knowledge for services to humanity.

- Provide adequate educational foundation for interested graduates to pursue higher degree in business education or other relevant areas in education.

In line with the above objectives, Ohiwerei and Azih (2010) summarized that business education is an educational programme in universities, which aim, among others, to educate individuals to become skilled employees who can contribute meaningfully to the overall effectiveness of an office, and produce effective teachers who can enhance teaching and learning in schools. To attain these objectives, universities that offer business education programme have deliberately reviewed their programme and courses to be in tune with the trend of ICT requirements of the global economy, by including modern technological gadgets and devices in their teaching and learning. Bongotons and Onyenwe (2010) noted that business education, in response to dynamic changes in processes and activities of business environment, has centered its delivery on technology, as there are traces of ICT integration into business education programme curricular of tertiary institutions. 


\subsection{Objective of the Study}

The aim of this study was to analyze the presence and inclusion of ICT skill courses in the business education programme of universities in South East, Nigeria.

\section{Literature Review}

\subsection{Business Education Programme and ICT}

Business education is an educational programme designed to continually move with the trends of time in order to meet with the needs and yearnings of the world of works. Njoku (2006) defined business education as an educational programme that equips an individual with functional and sustainable skills, knowledge, attitude and value that would enable individuals operate in the environment they find themselves. Azuka (2004) viewed business education as a programme of study which offers students who wish to pursue a career in business an opportunity to develop those skills, abilities and understanding that will enable them enter, perform and progress in a business occupation after graduation from high school or the university. The above definitions of business education programme portray it as a course of study that equips its recipient with the right skill and knowledge to succeed in business through the use of devices and facilities made available by technological innovations, which is the threshold of ICT.

ICT has been defined by diverse authors and writers. Aliyu (2003) defined ICT as the technology that is concerned with systems for creation, acquisition, processing, storage, retrieval, selection, transformation, dissemination and the use of vocal, pictorial, textual and numeral information. Nwabueze (2011) defined ICT as a broad-based technology which uses equipment, applications, methods and management that support the creation, storage, manipulation and communication of information. Federal Ministry of Education (2010a) defined ICT as encompassing all equipment and tools (inclusive of traditional technologies of radio, video and television to the newer technologies of computers, hardware, firmware etc), as well as the methods, practices, processes, procedures, concepts and principles that come into play in the conduct of the information and communication activities.

\subsection{ICT Skill Courses Required in Business Education Programme}

Skill is defined as abilities or proficiencies required of a person in a position to plan and execute an action geared at accomplishing some tasks or achieving some goals. It is the learned capacity to carry out predetermined tasks with the minimum outlay of time and energy (Ugwu and Ezeani, 2012). ICT skills can therefore be referred to as the ability of an individual to competently and proficiently manipulate technological devices for effective information gathering, organization, processing and retrieval.

ICT skill courses embedded in business education programme of universities in Nigeria according to NUC Benchmark Minimum Academic Standard (2007) includes: word processing which involves general competency in keyboarding and use of computer software like CorelDraw, Microsoft word, excel etc; application of computer; fundamentals of data processing; information management system; spreadsheet processing. Nwaokwa and Okoli (2012) noted that ICT revolution rendered skills such as transcription and typing skills on the manual typewriter obsolete and gave rise to previously unknown skills such as webpage design, desktop publishing, networking, internet skills etc. Ugwu and Ezeani (2012) mentioned professional ICT skill courses required by students for success in entrepreneurship venture as networking, database creation and management systems, desktop publishing, internet and intranet skills, presentation, hardware/software skills and relational databases including ability to create data structures which facilitates the indexing and retrieval of information, e-mail, multimedia perspectives and video conferencing. North Carolina Standard Course of Study-Computer Skills (2004) described the progressive development of knowledge and skills in six strands as societal and ethical issues, database management, spreadsheet, keyboard utilization/word processing, desktop publishing, multimedia/presentation and telecommunications/internet. Grant, Malloy and Murphy (2009) stated that in U.S business schools, word processing, spreadsheet applications, presentation, graphics and database management serves as the required information technology course for business students, as the skills are necessary to successfully matriculate throughout the business school, as well as to compete and secure future employment.

Researchers have noted the need for inclusion of ICT skill course such as word processing and spreadsheet skills (Chukwumezie and Ndinechi, 2006), Internet skills (Omeje, 2008), desktop publishing skills (Ramurez, 2009), PowerPoint presentation skills (Ementa and Ndinechi, 2012) in the business education programme. Azih (2010) however highlighted the need for the integration of more ICT courses into the curriculum of instruction of business education as the programme can only be relevant when it serves the society needs in producing ICT skilled graduates for the employment market. 


\section{ICT Courses of Business Education Programme in Universities in South East, Nigeria}

This paper is aimed at analyzing the four year standard academic programme on business education of five universities in South East, Nigeria namely: Ebonyi State University, Abakaliki; Enugu State University of Science and Technology, Agbani; Madonna University, Okija; Nnamdi Azikiwe University, Awka and University of Nigeria, Nsukka, to ascertain the presence of ICT skill courses in their programme.

Four-Year Standard Academic Programme in Business Education (Accounting and Secretarial Option) of Ebonyi State University, Abakaliki

\begin{tabular}{|c|c|c|c|}
\hline Year 1 & Year 2 & Year 3 & Year 4 \\
\hline $\begin{array}{l}\mathbf{1}^{\text {st }} \text { Semester } \\
\text { General Studies Courses } \\
\text { GST 101-Use of English I-2 } \\
\text { GST 102-Intro.to Logic \& Philosophy-2 } \\
\text { Core Courses } \\
\text { EDU 111-Intro.to Educational Psychology-2 } \\
\text { EDU 101-Hist Foundations of Education-2 } \\
\text { Specialization-(Secretarial \&Accounting Option) } \\
\text { BED 111-Intro.to General Biz-2 } \\
\text { BED 112-Shorthand I-2 } \\
\text { BED 113-Typewriting I-2 } \\
\text { BED 114-Elements of Accounting I-3 } \\
\text { BED 115- Foundations of Biz Education- } 2 \\
\text { Elective(Restricted) } \\
\text { ECO 101- Principles of Economics I-2 } \\
2^{\text {nd }} \text { Semester } \\
\text { General Studies Courses } \\
\text { GST 107-Use of English II-2 } \\
\text { Core Courses } \\
\text { EDU 102-Philosophical Foundations of Educ.- } 2 \\
\text { EDU 103-Sociological Foundations of Educ. -2 } \\
\text { Specialization-(Secretarial \&Accounting Option) } \\
\text { BED 121- Fundamentals of Marketing- } 2 \\
\text { BED 122- Shorthand II - } 2 \\
\text { BED 123- Typewriting II - } 2 \\
\text { BED 124- Elements of Accounting II - } 2 \\
\text { Elective(Restricted) } \\
\text { ECO 102- Principles of Economics II-2 }\end{array}$ & $\begin{array}{l}1^{\text {st }} \text { Semester } \\
\text { General Studies Courses } \\
\text { GST 103-Nigerian Peoples \& Culture -2 } \\
\text { Core Courses } \\
\text { EDU 211-Human Development-2 } \\
\text { EDU 221-Fundamentals of Curr.Dev-3 } \\
\text { Specialization-(Sec \& Accounting Option) } \\
\text { BED 201-SIWES in biz Education I-1 } \\
\text { BED 211-Record Management-2 } \\
\text { BED 212-Advanced Shorthand I-2 } \\
\text { BED 213-Production Typewriting-3 } \\
\text { BED 214-Intro.to Financial Accounting I -3 } \\
\text { Elective(Restricted) Sec \& Accounting) } \\
\text { ECO 211 - Micro Economics I - 2 } \\
\\
2^{\text {nd }} \text { Semester } \\
\text { General Studies Courses } \\
\text { GST 104-History \& Philo. Of Science-2 } \\
\text { Core Courses } \\
\text { EDU 222-Special Methods in biz Edu-3 } \\
\text { EDU 224-Educational Technology -2 } \\
\text { EDU 212-Human Learning-2 } \\
\text { Specialization-(Sec \& Accounting) } \\
\text { BED 221- Intro.to office Mgt-2 } \\
\text { Specialization (Sec Option Only) } \\
\text { BED 222-Advanced Shorthand II-2 } \\
\text { BED 223-2Production Typewriting II-2 } \\
\text { BED 226-Biz Statistics-2 } \\
\text { Specialization-Accounting Option Only) } \\
\text { BED 224-Intro. To Financial Accounting II-2 } \\
\text { Elective(Restricted) Sec \& Accounting } \\
\text { ECO 212-Micro Economics II - 2 }\end{array}$ & $\begin{array}{l}\text { 1st Semester } \\
\text { Core Courses } \\
\text { EDU 223-Teaching Practicel-3 } \\
\text { EDU 321-Curr \& Instruction-3 } \\
\text { Specialization-(Sec \& Accounting) } \\
\text { BED 301-SIWES in bus Education II-1 } \\
\text { BED 311-Bus \& Office Comm-2 } \\
\text { Specialization (Sec option only) } \\
\text { BED 312-Transcription I -3 } \\
\text { *BED 313-Format Typewriting/Word Processing I- } \\
\text { 3 } \\
\text { BED 315-Fundamentals of Small Bus Management -2 } \\
\text { Specialization-(Accounting Option) } \\
\text { BED 314-Financial Accounting III -2 } \\
\text { BED 316- Cost Accounting I-2 } \\
\text { BED 317- Taxation I } \\
\text { BED 331- Research Methods \& Statistics- 2 } \\
\text { Elective (Restricted) Sec Option) } \\
\text { CSC 101-Intro. To computer Science -2 } \\
2^{\text {nd }} \text { Semester } \\
\text { Core Courses } \\
\text { EDU 333-Educational Measurement \& Evaluation } \\
\text { Specialization-(Sec \& Accounting) } \\
\text { BED 321-Measurement \& Evaluation in Bus Educ-2 } \\
\text { BED 325-Fundamentals of Government Accounting-3 } \\
\text { BED 328-Business Law - 3 } \\
\text { Specialization - (Sec Option) } \\
\text { BED 322-Transcription II - 3 } \\
\text { *BED 323-Format Typewriting/Word Processing } \\
\text { II-2 } \\
\text { Specialization (Accounting Option) } \\
\text { BED 324- Financial Accounting IV- } 2 \\
\text { BED 326- Cost Accounting II - } 2 \\
\text { BED 327-Taxation II - } 2 \\
\text { Elective(Restricted) (Accounting Option) } \\
\text { CSC 101-Intro to Computer Science - 2 }\end{array}$ & 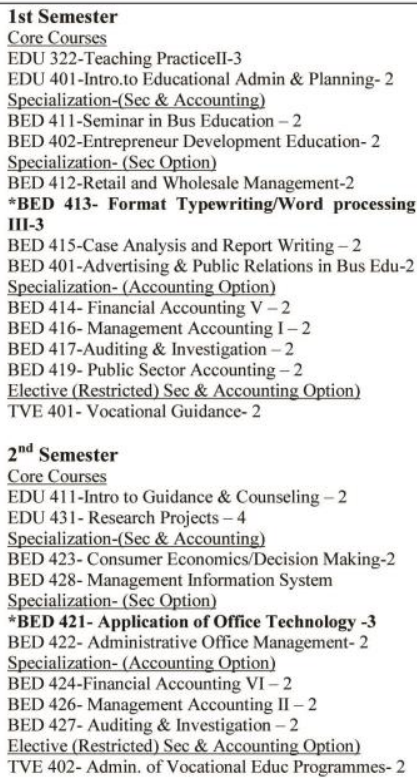 \\
\hline
\end{tabular}

* Indicates the presence of ICT course

Source: Academic Manual of Department of Business Education, EBSU, Abakaliki, ND.

ICT course in the programme is word processing. 
Four-Year Standard Academic Programme in Business Education (Accounting and Commerce Co-operative Option) of Enugu State University of Science and Technology, Agbani.

\begin{tabular}{|c|c|c|c|}
\hline Year 1 & Year 2 & Year 3 & Year 4 \\
\hline $\begin{array}{l}\text { First Semester } \\
\text { GST 101-Use of English I -2 } \\
\text { GST 102-Nigerian Peoples \& Culture -2 } \\
\text { CSE 100- Computer Appreciation - } 2 \\
\text { EDU 101-History of Education-2 } \\
\text { EDU 111-Intro.to Educational Psychology-2 } \\
\text { BED 111-Principles of Business Education-2 } \\
\text { ACC 101-Principles of Accounts I - } 3 \\
\text { BUS 101-Introduction to Business I-2 } \\
\text { ECO 101-Principles of Economics I-2 } \\
\text { TVE 101- Intro. To tech \& Voc .Education - } 2 \\
\text { Accounting Option Only } \\
\text { MAT 103-Business Mathematics I - } 2 \\
\text { Second Semester } \\
\text { GST 101-Use of English - 2 } \\
\text { GST 102-Nigerian Peoples \& Culture - } 2 \\
\text { CSE 100- Computer Application II - } 2 \\
\text { EDU 101-History of Education - } 2 \\
\text { EDU 111-Intro.to Educational Psychology - } 2 \\
\text { BED 111-Principles of Business Education - } 2 \\
\text { ACC 102-Principles of Accounts I - } 3 \\
\text { Accounting Option Only } \\
\text { MAT 103- Business Mathematics I - } 2\end{array}$ & 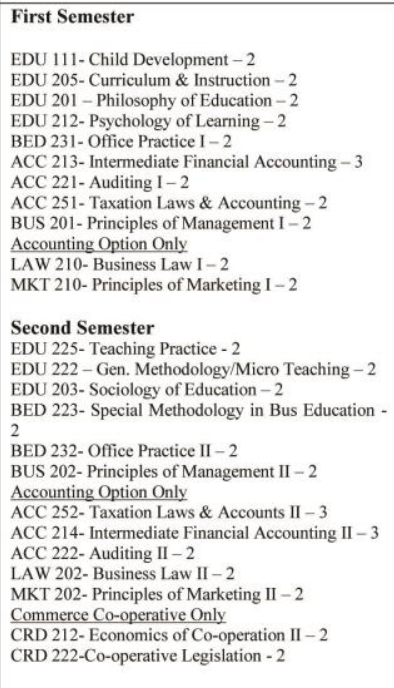 & 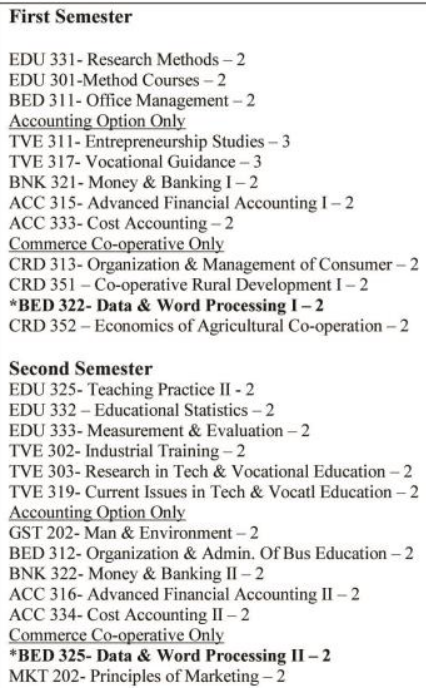 & 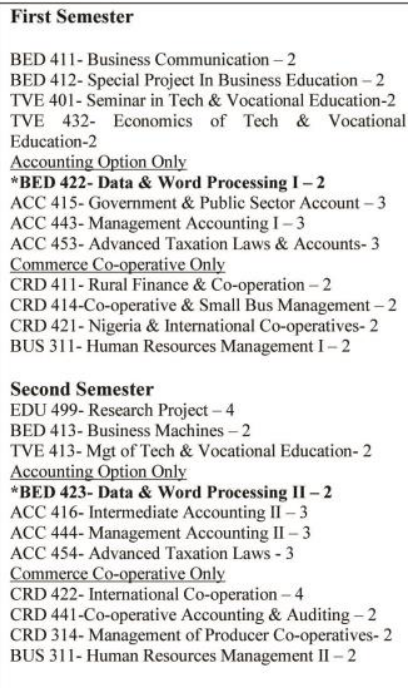 \\
\hline
\end{tabular}

\section{* Indicates the presence of ICT course}

Source: Handbook of Department of Technology and Vocational Education Standard Degree Programmes in Technology Education, Enugu State University of Science and Technology (ESUT), October 2007.

ICT course in this programme is data/word processing.

Four Year Standard Degree Programme of Business Education Department, Madonna University, Okija

\begin{tabular}{|c|c|c|c|}
\hline 100 Level & 200 Level & 300 Level & 400 Level \\
\hline 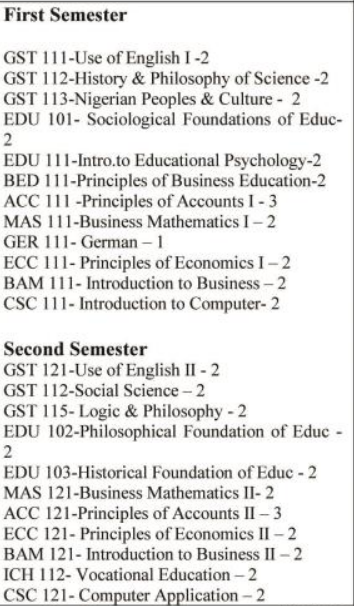 & 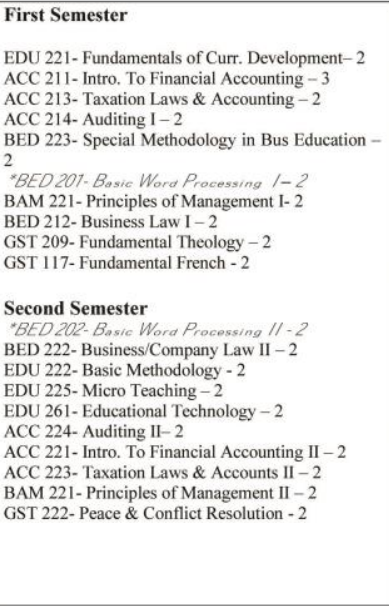 & 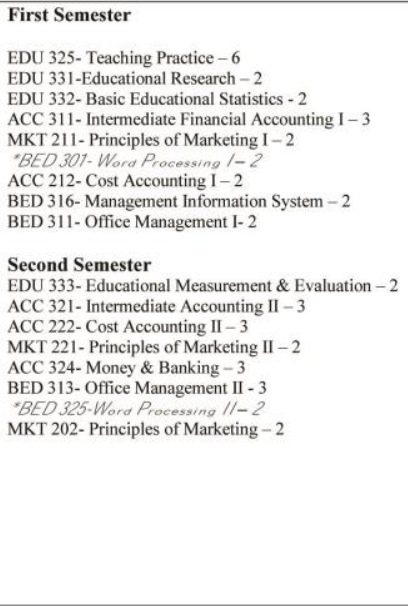 & 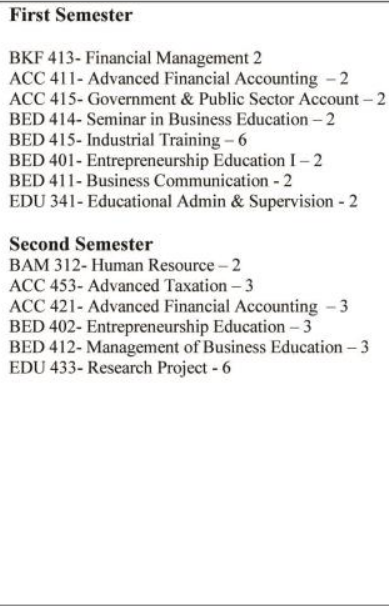 \\
\hline
\end{tabular}

\section{*Indicates the presence of ICT Course}

Source: Madonna University, Okija Department of Business Education Handbook, 2011.

ICT skill course in the programme is word processing. 
Four Year Academic Standard Programme of Business Education Programme (Accounting, Commerce Co-operative and Secretarial Technology Option), Nnamdi Azikiwe University, Awka.

\begin{tabular}{|c|c|c|c|}
\hline Year 1 & Year 2 & Year 3 & Year 4 \\
\hline 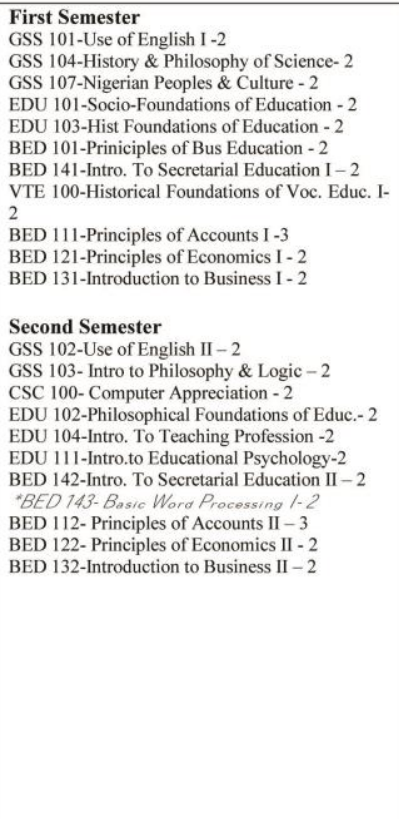 & $\begin{array}{l}\text { First Semester } \\
\text { LAW 201- Business Law I-2 } \\
\text { STA 101-Intro. To Business Statistics - } 2 \\
\text { EDU 212-Psychology of Learning -2 } \\
\text { EDU 221-Foundations of Curriculum. Dev.- } 2 \\
\text { EDU 222-Basic Methodology - } 2 \\
\text { *BED 244-Basic Word Process/ng // - } 2 \\
\text { BED 233-Secretarial Procedure I -2 } \\
\text { BED 213-Intermediate Fin. Accounting I - } 2 \\
\text { Restricted Electives } \\
\text { BED 215-Intro. To Cost \& Mgt Accounts I-3 } \\
\text { BNK 321- Money \& Banking I - } 2 \\
\text { Commerce Co-operative Option Only } \\
\text { CEM 101 - Intro. To Co-operation - } 2 \\
\text { Second Semester } \\
\text { LAW 202- Business Law II - 2 } \\
\text { BUS 222- Business Statistics - } 2 \\
\text { EDU 261- Educational Technology - } 2 \\
\text { EDU 223-Special Methodology - } \\
\text { EDU 225-Micro Teaching Practical -2 } \\
\text { BED 235- Business Machines - } 2 \\
\text { BED 234- Secretarial Procedure II - } 2 \\
\text { Restricted Electives } \\
\text { BED 216-Intro. To Cost \& Mgt Accounting II - } 3 \\
\text { BNK 322-Money \& Banking II - } 2 \\
\text { Commerce Co-operative Option Only } \\
\text { CEM 102 -Principles \& Practice of Co-operation- } \\
2\end{array}$ & 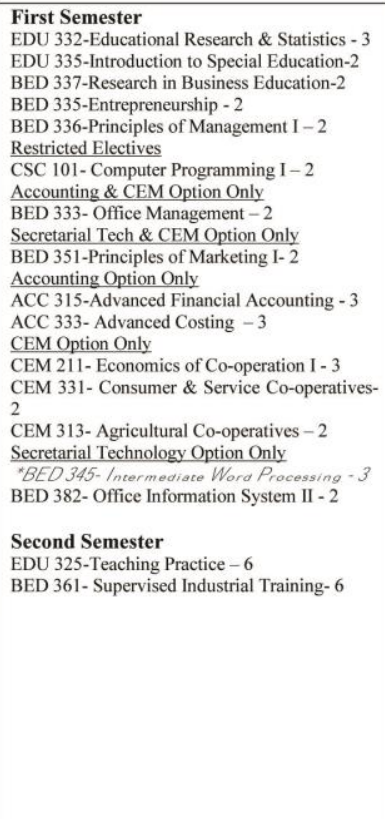 & 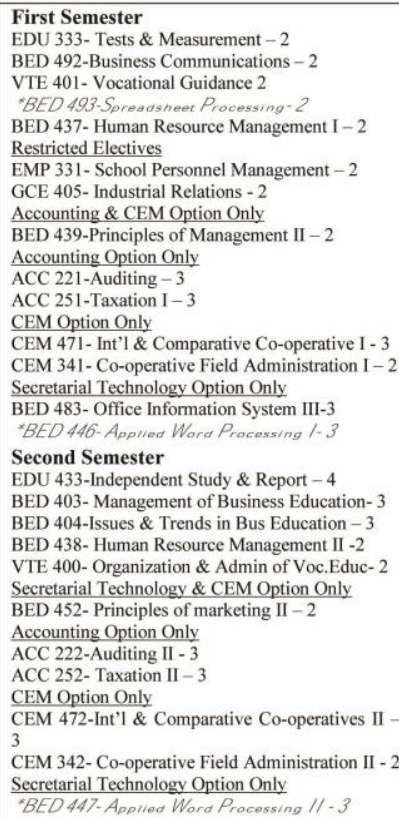 \\
\hline
\end{tabular}

\section{*Indicates the presence of ICT Course}

Source: Manual for Undergraduate Business Education Students, Department of Vocational Education, Nnamdi Azikiwe University, Awka, 2011.

ICT courses in the programme are word processing, computer programming and spreadsheet processing.

\section{Four Year Standard Programme in Business Education, University of Nigeria, Nsukka}

\begin{tabular}{|c|c|c|c|}
\hline First Year & Second Year & Third Year & Fourth Year \\
\hline 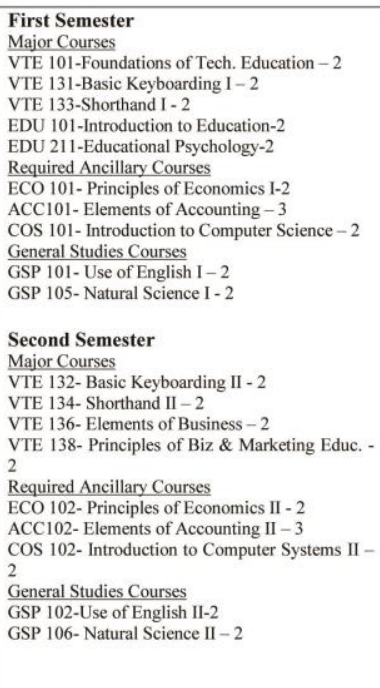 & 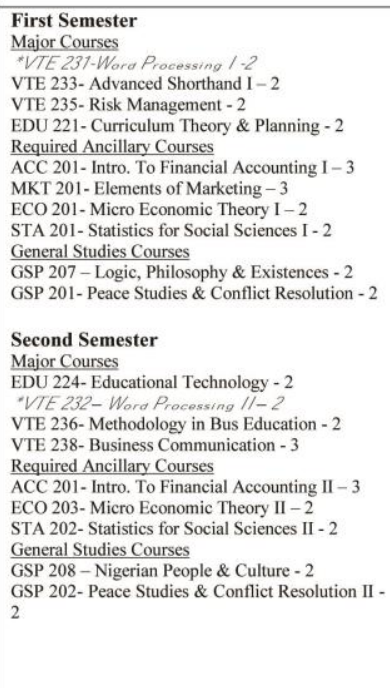 & $\begin{array}{l}\text { First Semester } \\
\text { Major Courses } \\
\text { VTE 301- Industrial Work Experience I-1 } \\
\text { VTE 331- Biz Organisation - } 2 \\
\text { VTE 333- Biz Law \& Govt Regulations - } 2 \\
\text { EDU 331-Educational Psychology II - } 2 \\
\text { EDU 321-Curriculum Implementation \& Instruction- } \\
3 \\
\text { EDU 325- Teaching Practice - } 3 \\
\text { Required Ancillary Courses } \\
\text { MKT 301- Nigerian Mkt Sys. \& Commercial Policy - } \\
3 \\
\text { ACC 251- Fundamentals of Govt Accounting - } 3 \\
\text { CED 341- Intro. To Entrepreneurship - } 2\end{array}$ & 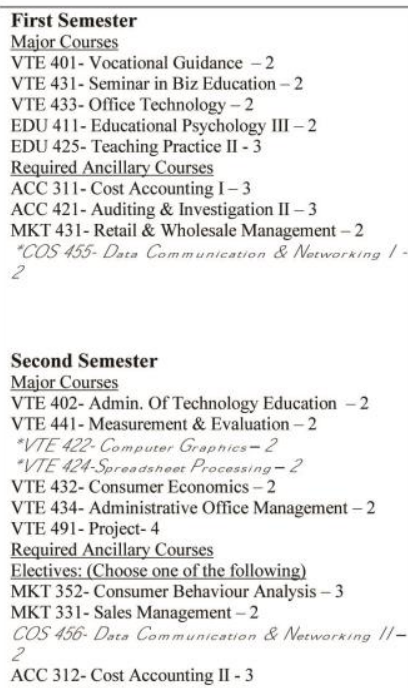 \\
\hline
\end{tabular}

\section{*Indicates the presence of ICT Course}

Source: Handbook of Vocational Teacher Education, University of Nigeria, Nsukka, 2006.

ICT courses in the programme are word processing, computer applications, computer graphics, spreadsheet processing and data communication and networking. 


\subsection{Discussion of Findings}

The four year standard business education programme of Ebonyi State University, Abakaliki has two options namely accounting and secretarial option. A careful observation of the programme handbook shows that only one ICT course (word processing) offered in $3^{\text {rd }}$ and $4^{\text {th }}$ year to secretarial students, and no ICT course offered to accounting students of the programme. This implies that secretarial students are the only group of students exposed to word processing while accounting students are not taught any ICT course throughout the duration of the programme. This makes one wonder if accounting students do not require ICT knowledge and skill in preparedness for the world of work.

A look at the business education programme handbook of Enugu State University of Science and Technology, Agbani shows that business education programme has two options namely accounting and commerce co-operative. The only ICT course in the programme is data/word processing, offered to commerce co-operative students in the $3^{\text {rd }}$ year, and accounting students in the $4^{\text {th }}$ year. This implies that the ICT course the students are exposed to is data/word processing in the two semesters out of the eight semesters they spend in school.

A careful observation of the handbook of business education programme of Madonna University, Okija shows that the programme offers to its students one ICT course, word processing offered to the students at the 2 nd and $3^{\text {rd }}$ year. This implies that the students are exposed to only one ICT course in four semesters out of eight semesters spent in school. One starts to wonder if word processing is the only ICT course needed to effectively prepare students for the business/industry and for self-reliance.

An examination of the handbook of business education programme of Nnamdi Azikiwe University, Awka shows that the programme has three options - accounting, commerce co-operative and secretarial technology option. ICT courses in the programme are word processing, computer programming and spreadsheet processing. Word processing is offered as a basic and general course to all students in the $1^{\text {st }}$ and $2^{\text {nd }}$ year, and secretarial students are to carry on with the intermediate and applied word processing in $3^{\text {rd }}$ and $4^{\text {th }}$ year respectively. Computer programming is offered to the students as an elective for only one semester in the $3^{\text {rd }}$ year, while spreadsheet processing is offered to the students in one semester in the $4^{\text {th }}$ year. The doubt comes to mind if offering computer programming as an elective in one semester alone can effectively prepare a student to initiate and design computer software programmes and applications.

A careful look at the Vocational Teacher Education (VTE) handbook of University of Nigeria Nsukka shows that the business education programme offers its students four ICT courses namely; word processing, computer applications, computer graphics, spreadsheet processing and data communication and networking. Word processing is offered to the students throughout $2^{\text {nd }}$ year; computer applications is offered as a required ancillary course in $2^{\text {nd }}$ semester of third year; computer graphics is offered in second semester of $4^{\text {th }}$ year; and data communication and networking is a required ancillary course which students are compulsorily required to study in the first semester of $4^{\text {th }}$ year, and in second semester as an elective. One would wonder if offering these five ICT courses in bits can adequately expose the students to the knowledge and acquaintance of the skills provided therein.

The findings of this study is in line with the findings of Ezeani and Ishaq (2013) who reported that graduates of business education programme in Nigerian universities are not adequately exposed to ICT skills. The findings of this study also corroborated with the findings of Ezeani and Akpotohwo (2014) who noted that students' performance towards exhibiting ICT skills is questionable. This is with regards to students' exposure to ICT skills in the institutions.

\subsection{Conclusion}

Discussion of the findings in the business education programme handbook of the five listed universities in South-East, Nigeria reveals that generally, the programmes lack ICT skill acquisition courses. ICT courses offered to the students of business education programme are limited to word processing and spreadsheet processing. Institutions that offer more than two ICT courses to its students, offer them in bits as one semester course.

Studies could be carried out on other areas that are relative to skill acquisition in relation to webpage design, desktop publishing, graphics and corel design etc.

\subsection{Implication of the Study}

The result of this paper has brought to the fore the need for the various aspects of ICT to be integrated into the business education programme of universities in South East, Nigeria to make their products versatile in the use of diverse ICT protocols. 


\subsection{Recommendations}

From the conclusion above, the following recommendations are made;

Association of Business Educator of Nigeria, National Universities Commission, Federal Ministry of Education and other regulatory bodies should ensure and enforce a total overhaul and review of business education curriculum of universities to integrate more ICT skill courses/programs such as PageMaker, PowerPoint, desktop publishing, graphic designs, database management, Access, Sage \& Peachtree accounting courses in the programme as to breed and produce graduates who can fit effectively in today's workplace possessing required ICT skills.

Association of Business Educators of Nigeria (ABEN) and National Universities Commission should harmonize the ICT courses in the programme of universities so that what is obtainable in one university can be obtained in another.

Government at local, state and federal levels should partner and liaise with heads of management of business education programmes in universities to adequately fund the programmme with modern ICT infrastructural equipment/facilities.

Management of universities should recruit staff that possess competent ICT qualification, and re-train in-service business educators in line with modern technologies as to inculcate and imbibe workplace relevant ICT skills in the students.

\section{References}

Ajaero, O.O. (2010). Enhancing Accounting Education in Tertiary Institutions in Nigeria: The Role of ICT. Association of Business Educators of Nigeria Book of Readings, 1 (10), 34-40.

Aliyu, I. (2003). Business Teacher Education in an Information Technology Era. A Paper presented at the maiden conference of School of Vocational Education, Federal College of Education, Kano, $29^{\text {th }}$ July- $2^{\text {nd }}$ August.

Azih, N. (2010). Modern Accounting Skills Required by Accounting Education Students. Business Education Journal, 7(2), 120-130.

Azuka, E.B (2004). Standards in Business Education in Nigerian Universities: A Critical Analysis and the Way Forward. Business Education Book of Reading, 1(4), 22-25.

Bongotons, Y.B \& Onyenwe, B. O. (2010). Availability and Adequacy of ICT Resources in Business Teacher Education Programmes of Nigeria. Business Education Journal, 7(2), 200-214.

Chukwumezie, F.U \& Ndinechi, G.I. (2006). Word Processing and Electronic Spreadsheets Sub-skills Required of Secretaries for Office Career Opportunities in Private Organizations. Business Education Journal, 5(2), 138-149.

Ementa, C.N \& Ndinechi, G.I. (2012). Business Education Students Rating of the Teaching of Word Processing and Desktop Publishing Skills in Tertiary Institutions in South East Nigeria. A Paper Presented at the annual conference of Association of Business Educators of Nigeria (ABEN) at Federal Polytechnic, Nekede, $16^{\text {th }}-20^{\text {th }}$ October.

Etonyeaku, E.A.C. (2012). Utilization of ICT in Business Teacher Education Programme for Quality Assurance in Government Tertiary Institutions in Enugu State, Nigeria. A Paper presented at the Annual Conference of Association of Business Education of Nigeria (ABEN) in Federal Polytechnic, Nekede, 16-20 ${ }^{\text {th }}$ October

Ezeani, N. S \& Ishaq, A.M. (2013). Emerging issues in business education: A panacea for effective utilization and application of ICTs as a tool in business education in Nigerian universities. Review of Public Administration and Management, 1(2), 89-107.

Ezeani, N. S. \& Akpotohwo, F. C. (2014). Integrating information and communication technology (ICT) in accounting education instruction in Ekiti state universities. International Journal of Business and Social Science, 5(6), 195-204.

Federal Ministry of Education. (2010a). National Policy on Information and Communication Technologies (ICT) in Education. Abuja: FME.

Grant, D.M; Malloy, A.D \& Murphy, M.C. (2009). A Comparism of Student Perception of their Computer Skills to their Actual Abilities. Journal of Information Technology Education, 8.

Njoku, C.U. (2006). Business Education and Value Orientation for National Economic Empowerment and Development. A Paper presented at Owo 2006 annual conference of Association of Business Educators of Nigeria (ABEN). 
North Carolina Standard Course of Study-Computer Skills. (2004). The K-12 Computer/Technology Skills Standard Course of Study. Retrieved from http://www.ncpublicschools.org/curriculum /computerskills/scos/

National Universities Commission (NUC). (2007). Benchmark Minimum Academic Standards for Undergraduate Programmes in Nigerian Universities. Abuja: NUC.

Nwabueze, A.U (2011). Information and Communication Technology for Sustainable Development in Nigeria. Retrieved from http://www.faqs.org/periodicals

Nwaokwa, E \& Okoli, B.E. (2012). Information and Communication Technology on the Influence Performance of Secretaries in Government Ministries in Nasarawa State, North-Central, Nigeria. Research Journal of Information Technology, 4(3), 93-97.

Ohiwerei, F.O \& Azih, N. (2010). Comparative Programmes of Business Education in Nigerian Universities. A Case Study of Ambrose Ali University, Ekpoma and Delta State University, Abraka. Current Research Journal of Social Sciences 2(2), 58-64.

Omeje, T.S. (2008). Imperatives for Reforming the Secretarial Studies Curriculum in Nigeria. Business Education Journal, 2(1), 27-37.

Ramirez, L (2009). What is Desktop Publishing? Some History and an Answer. Retrieved from www.selfpublishbooks.com

Ubulom, W.J; Enyekit, E.O; Onuekwa, F.A and Amaehule, S. (2011). Analysis of Information and Communication Technology (ICT) Accessibility and Utilization in Teaching Business Studies in Secondary Schools in Andoni L.G.A, Rivers State, Nigeria. Proceeding of the 2011 International Conference on Teaching, Learning and Change.

Ugwu, F \& Ezeani, C.N. (2012). Evaluation of Entrepreneurship Awareness and Skills among LIS students in Universities in South-East Nigeria. Library, Philosophy and Practice. 